2002

\title{
Sentencing Policies and Practices in the International Criminal Tribunals
}

\author{
Mark A. Drumbl \\ Kenneth S. Gallant \\ University of Arkansas at Little Rock William H. Bowen School of Law, ksgallant@ualr.edu
}

Follow this and additional works at: http://lawrepository.ualr.edu/faculty_scholarship

Part of the International Law Commons, and the Military, War and Peace Commons

\section{Recommended Citation}

Mark A. Drumbl \& Kenneth S. Gallant, Sentencing Policies and Practices in the International Criminal Tribunals, 15 Fed. Sent. R. 140 (2002).

This Article is brought to you for free and open access by Bowen Law Repository: Scholarship \& Archives. It has been accepted for inclusion in Faculty Scholarship by an authorized administrator of Bowen Law Repository: Scholarship \& Archives. For more information, please contact mmserfass@ualr.edu. 


\section{Sentencing Policies and Practices in the International Criminal Tribunals}

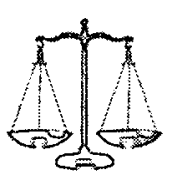

MARK A. DRUMBL

Assistant Professor,

School of Law,

Washington \& Lee

University. E-Mail:

drumblm@wlu.edu.

\section{KENNETH S. GALLANT}

Professor, William $\mathrm{H}$. Bowen School of Law, University of Arkansas at Little Rock. E-Mail: ksgallant@ualr.edu.

\section{Introduction}

The sentencing of individuals convicted of genocide, crimes against humanity, and war crimes is a complex undertaking. These crimes share a number of features that differentiate them from other crimes. For example, they tend to arise from collective pathologies such as myths of religious or ethnic superiority, may be manifestly illegal but not necessarily illegal in the place where they were committed, are of extreme barbarity, affect large numbers of victims, and involve a substantial segment of the population as perpetrators, organizers, or acquiescent bystanders. In addition, they often take place in times of chaos (including during armed conflict) and are prosecuted in times of reconstruction. Accordingly, prosecutions serve multiple purposes. Moreover, sentences must balance multiple considerations. These include retributive, incapacitative and rehabilitative goals; individual and general deterrence; societal reconciliation and reconstruction; reparation; forgiveness; and atonement.

For the most part, sentencing those who perpetrate mass atrocity is a novel exercise. The military tribunals established at Nuremberg and Tokyo following World War II did not elucidate sentencing guidelines. Nor has there been much scholarly research to develop a theory of sentencing for mass violence. Because of this vacuum, the recently established ad hoc International Criminal Tribunals for the former Yugoslavia (ICTY) and Rwanda (ICTR) (jointly referred to as the Tribunals) remain at the forefront of developing a sentencing policy and practice for the most egregious crimes against the world community. The International Criminal Court (ICC), which came into effect on July I, 2002, albeit without US membership, will become a permanent international institution to prosecute the most serious crimes of concern to the international community as a whole.

This Article provides an overview of the sentencing framework of the ad hoc Tribunals. It also explores some important sentencing aspects of the ICC. The work of the ICTY and ICTR is recent. As such, it is difficult to speak of a settled sentencing practice, but it is possible to delineate a fledgling sentencing practice.' One important initial observation is that ICTY and
ICTR sentences for extraordinary criminals who perpetrate mass crimes of the most egregious nature can be less severe than those for ordinary criminals in the United States and many other countries.

\section{The Tribunals}

\section{A. Jurisdiction}

The ICTY was created by the United Nations Security Council in 1993. Its mandate is to prosecute persons responsible for genocide, crimes against humanity, and war crimes committed on the territory of the former Yugoslavia since 1991. This includes the multi-ethnic violence among Croats, Serbs, Bosnian Muslims, and Albanians that occurred in Bosnia-Herzegovina, Kosovo and Croatia. This violence resulted in the deaths of approximately 250,000 individuals.

The ICTR's mandate covers crimes committed in Rwanda in 1994, when an extremist government comprised of members of Rwanda's Hutu ethnic group orchestrated the genocide of approximately 800,000 Rwandans, mostly members of the Tutsi ethnic group, although approximately 30,000 Hutu also were murdered. Whereas the ICTR's jurisdiction is timelimited to 1994, the ICTY's jurisdiction has no ending date. This permits the ICTY to have jurisdiction over events that occurred following its creation, such as the 1998-1999 violence in Kosovo.

Readers unfamiliar with the details of international criminal law may have difficulty separating genocide, crimes against humanity, and war crimes, or may even view these as somewhat indistinguishable. There are, however, important definitional distinctions among these crimes. Genocide means killing or causing serious harm to members of a national, ethnic, racial or religious group with the intent to destroy that particular group, in whole or in part. Proof of this mental element - the intent to destroy - is one factor that distin. guishes genocide from crimes against humanity and war crimes. Broadly speaking, crimes against humanity involve a series of acts -including murder, enslavement, extermination, deportation, persecution, rape, and torture - that are committed as part of a widespread or systematic attack directed against any civilian population. ${ }^{2}$ War crimes cover two sorts of activities: (I)

Federal Sentencing Reporter, Vol. 15, No. 2, pp. I40-44, ISSN 1053-9867, electronic ISSN 1533-8363. (C) 2003 by the Vera Institute of Justice. All rights reserved. Send requests for permission to reprint to: Rights and Permissions, University of California Press, Journals Division, 2000 Center Street, Suite 303. Berkeley, CA 94704-1223. 
crimes committed in international armed conflict such as wilful killing, torture, and inhumane treatment; and (2) violations of the laws and customs of war, a residual category that can apply to internal armed conflicts. A broader array of conduct is prohibited in international armed conflict than in internal armed conflict; civilians and prisoners are accorded more protection during international armed conflict than internal armed conflict.

\section{B. Structure}

The Tribunals have separate Trial Chambers. They share common appeals judges, although each Tribunal formally has its own Appeals Chamber. The seat of the ICTY is in The Hague, Netherlands. The seat of the ICTR is in Arusha, Tanzania. The Tribunals also share a single Prosecutor, although the Deputy Prosecutors differ. The Tribunals are temporary ad hoc institutions and the conventional wisdom is that the trials they conduct will wrap up in 2008 , although appeals and other administrative matters will continue beyond that date.

There is a broad scope of appeal. Defendants and the Prosecution both can appeal judgments. Both also can appeal the sentences imposed by the Trial Chambers. ${ }^{3}$ Many such sentence appeals currently are pending. The number of pending appeals further contributes to the reality that the Tribunals have not yet attained a predictable pattern of sentencing.

\section{Detainees}

As of July 29, 2002, the ICTY had 56 detainees in custody, with an additional Io on provisional release; the ICTR had 59 detainees in custody. Many of these individuals are the leaders and planners of mass atrocity, although the ICTY has successfully prosecuted a number of lower-level organizers and participants in group violence. A number of individuals remain fugitives from arrest warrants, particularly in the case of the ICTY where some notorious instigators of the violence, such as Radovan Karadzic and Gen. Ratko Mladic, remain at large.

\section{The Regulatory Framework for Sentencing} The ICTY and the ICTR each were created by Statute adopted by the Security Council. In addition, they are guided by Rules of Procedure and Evidence. Both the Statutes and the Rules address sentencing issues.

Article $23(\mathrm{I})$ of the ICTY Statute provides that "[t]he Trial Chambers shall pronounce judgements and impose sentences and penalties on persons convicted of serious violations of international humanitarian law." Article 24 provides some elaboration. By limiting possible penalties to imprisonment, the Statute precludes the death penalty. Also, the Trial Chambers may order the return of any property and proceeds acquired by criminal conduct, including by means of duress, to their rightful owners. Other than disgorging gains of criminal conduct, the Tribunals cannot order restitution for damage done to persons or property. There are also no provisions for "alternative sentences" that might form part of a more comprehensive system of restorative justice.

Article 24(I) goes on to state that, in determining the terms of imprisonment, the Trial Chambers shall have recourse to the general practice regarding prison sentences in the courts of the former Yugoslavia. This reference dilutes the suggestion that the ICTY is engaging in retrospective law-making. Article 24(2) provides additional, and important, guidance. It says that, in imposing the sentences, the Trial Chambers should take into account (not must or shall take into account) such factors as the gravity of the offense and the individual circumstances of the convicted person.

Articles 22 and 23 of the Statute of the ICTR provide virtually identical provisions. The limitation of the ICTR to impose imprisonment sentences is especially important in the case of Rwanda. The "general practice regarding prison sentences in the courts of Rwanda" includes the death penalty. In fact, a number of death sentences have been carried out against notorious genocidal murderers convicted in domestic trials in Rwanda. This leads to a paradox: the high-level organizers of the Rwandan genocide over whom the ICTR has custody may receive lower sentences than those less serious offenders tried by national courts.

Article 26 of the ICTR Statute stipulates that: "Imprisonment shall be served in Rwanda or any of the States on a list of States which have indicated to the Security Council their willingness to accept convicted persons, as designated by the International Tribunal for Rwanda. Such imprisonment shall be in accordance with the applicable law of the State concerned, subject to the supervision of the International Tribunal for Rwanda." At the time of writing, six ICTR convicts are incarcerated in Mali. A similar provision is found in Article 27 of the ICTY Statute, although no mention is made of imprisonment being served in the Federal Republic of Yugoslavia, or any other country formerly part of Yugoslavia. At present, ICTY detainees serving sentence are doing so in Germany, Finland, Spain, Austria, and Norway.

The provisions of the Statutes are supplemented by the Rules of Procedure and Evidence. ICTY Rule IOI is worth reproducing in its entirety, because it sets forth some factors to guide sentencing decisions:

(A) A convicted person may be sentenced to imprisonment for a term up to and including the remainder of the convicted person's life.

(B) In determining the sentence, the Trial Chamber shall take into account the factors mentioned in 
Article 24, paragraph 2, of the Statute, as well as such factors as:

(i) any aggravating circumstances;

(ii) any mitigating circumstances including the substantial cooperation with the Prosecutor by the convicted person before or after conviction;

(iii) the general practice regarding prison sentences in the courts of the former Yugoslavia;

(iv) the extent to which any penalty imposed by a court of any State on the convicted person for the same act has already been served, as referred to in Article 1o, paragraph 3, of the Statute [prohibiting double punishment, except where punishment in a national court was for an "ordinary" rather than an international crime, or where the case was brought in the national court essentially to protect the accused from facing a fair, vigorous international prosecution].

(C) Credit shall be given to the convicted person for the period, if any, during which the convicted person was detained in custody pending surrender to the Tribunal or pending trial or appeal.

Rule IOI of the ICTR Rules essentially is identical, although it adds the following provision to the text set out above: "IOI (C) The Trial Chamber shall indicate whether multiple sentences shall be served consecutively or concurrently." Rule $87(\mathrm{C})$ of the ICTY Rules explicitly provides that "[i]f the Trial Chamber finds the accused guilty on one or more charges contained in the indictment, it shall impose a sentence in respect of each finding of guilt and indicate whether such sentences shall be served consecutively or concurrently, unless it decides to exercise its power to impose a single sentence reflecting the totality of the criminal conduct of the accused."

As is the case in most civil law jurisdictions, sentencing does not occur within a separate sentencing phase but occurs as part of the guilt or innocence (judgment) phase. Sentencing may be addressed in closing arguments. One American observer suggests that the decision not to proceed in two separate proceedings might also have been related to "an effort to save time and money,"s both of which are sensitive issues for the Tribunals. The Rome Statute of the ICC, on the other hand, appears to favor a separate sentencing hearing. ${ }^{6}$

The ICC also authorizes imprisonment. The ICC will be able to sentence a convict to up to thirty years imprisonment, with a possibility of "life imprisonment when justified by the extreme gravity of the crime and the individual circumstances of the convicted person."? The ICC, only in addition to imprisonment, will have authority to order a fine, and may order forfeiture of assets derived directly or indirectly from the crime.
Fines and forfeitures may be placed in a Trust Fund established by the Court for the benefit of victims and their families. ${ }^{8}$ Thus, the ICC Statute pays somewhat more attention to restorative justice goals than do the Statutes of the ad hoc Tribunals.

\section{Practice}

As of July 29, 2002, the ICTY had convicted 28 defendants. ${ }^{9}$ Many of these convictions currently are under appeal. Three convicts already have served their sentences. An additional four defendants had been convicted by the Trial Chamber, only to be acquitted on appeal (the sentences were therefore dismissed). The ICTR, for its part, has convicted eight defendants and has acquitted one. ${ }^{\text {to }}$

Sentences at the ICTY range from 5 to 46 years imprisonment. As of July 29, 2002, the mean sentence based on our calculations is 16 years; the median sentence is 15 years. Sentences at the ICTR range from 12 years to life imprisonment. Of the eight convictions, five have resulted in a life sentence, three in sentences of $\mathrm{I} 2,15$, and 25 years, respectively.

\section{A. Is There a Hierarchy of International Crimes for Sentencing Purposes?}

Tribunal practice demonstrates that the type of crime committed is very important to, but does not fully control, the sentencing decision. The specific facts of the crime and the circumstances of the defendant are considered in making the sentencing decision.

By and large, ICTR sentences are more severe than ICTY sentences. This may very well be due to the fact that the ICTR has issued more genocide convictions than the ICTY. It is apparent from the sentencing practices of the Tribunals that sentencing judges view

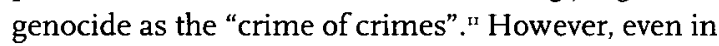
cases where the two ad hoc Tribunals convicted for genocide, their sentencing practices have not been identical. Whereas the ICTY has issued a maximum sentence of 46 years to a genocide convict (General Radislav Krstic), the ICTR repeatedly has issued life sentences (at times multiple life sentences) to such detainees (for example, Jean Kambanda, Alfred Musema and Jean-Paul Akayesu).

It may be that genocide draws a heavier punishment solely because the cases are characterized as genocide rather than war crimes or crimes against humanity. It also may be that the cases prosecuted as genocide draw higher sentences because they are the very worst cases, involving the greatest number of deaths. Statements that genocide is the "crime of crimes" deserving of the heaviest punishment are frequent in the Trial Chambers, the entities charged with principal responsibility for sentencing. ${ }^{12}$ However, the Appeals Chambers, despite opportunity to make statements that genocide formally should be sentenced more severely than other 
crimes, generally have refrained from doing so explicitly, choosing instead to examine whether the facts of a given case justify the penalty imposed. ${ }^{3}$ Moreover, because the specific circumstances of the crime and the criminal "should" be considered in sentencing, ${ }^{14}$ sentences for the crime of genocide, like other crimes in the jurisdiction of the Tribunals, may vary. However, within each of the Tribunals, there is greater consistency among sentences for genocide convictions than among sentences for convictions of crimes against humanity. In fact, there is particular variability among sentences for crimes against humanity within the ICTY, which may reflect the ICTY's choice to prosecute a broad range of individuals occupying various levels of the command structure.

The formal ranking of crimes against humanity as more serious than war crimes has been rejected by the ICTY Appeals Chamber. It has held that there is no presumptive distinction between war crimes and crimes against humanity with respect to their seriousness or the severity of the punishment they should attract. ${ }^{\text {is }}$ The decision, however, was not unanimous. Judge Cassese dissented, arguing that the additional element of a crime against humanity - "knowledge that the criminal conduct is part of a widespread or systematic practice" $^{16}$ - justifies treating it more severely than the same act charged as a war crime. Moreover, in practice, cases charged as war crimes tend to attract lower sentences than cases charged as crimes against humanity, but this may well be because the cases prosecuted as crimes against humanity may be more horrific, usually in terms of numbers of people killed, than most crimes prosecuted as war crimes.

The ICC continues the practice of the ICTY and ICTR Statutes, in that it authorizes identical maximum sentences for genocide, war crimes, and crimes against humanity.

\section{B. Guilty Pleas}

The practice of ICTY and ICTR Prosecutors is to permit guilty pleas. This reflects an incorporation of criminal practice from common law countries, given that guilty pleas do not form part of the Western European civil law tradition, at least not for such serious offenses. They have, however, been incorporated into domestic Rwandan legislation for the prosecution of crimes related to the Rwandan genocide. By and large, pleading guilty and cooperating with the Tribunals is viewed as a mitigating factor in sentencing. ${ }^{\text {17 }}$ For example, if the three individuals who pleaded guilty at the ICTR are taken out of the equation, overall ICTR sentences become four life sentences and one 25 year sentence. The two lowest ICTR sentences, both 12 years, have involved guilty pleas.

\section{Factors Guiding Sentencing Discretion}

The judges of the Tribunals have broad discretion in terms of sentencing, including the weight to attribute to various factors and considerations. There is no minimum sentence. Moreover, it has been held that the criteria specified within the Statute and Rules for sentencing - for example, following the general sentencing practice in either Rwanda or the former Yugoslavia - do not bind the Trial Chambers in the determination of a sentence. ${ }^{8} \mathrm{~A}$ review of the case-law of the Tribunals reveals the consideration of a number of factors in determining sentence, many of these being specific examples of the broad guidance provided by the Rules and Statutes. Specific factors include, but are not limited to: the position of an accused in the command structure (senior position with command authority as an aggravating factor, low-level position as a mitigating factor);:19 the accused's attitude toward the victims;,;0 remorse and co-operation with the Tribunals; ${ }^{21}$ the sheer inhumanity of the crimes; ${ }^{22}$ and the youth of the accused (as a mitigating factor) ${ }^{23}$ and of the victims (as an aggravating factor). ${ }^{24}$

Many different rationales for sentencing - deterrence (whether general or specific), retribution, incapacitation, and rehabilitation - are evoked in different cases. One cannot yet quantify how much each rationale or each factor contributes to sentences generally. However, what can be clearly seen are both strengths and weaknesses of the open-ended sentencing structure of the Statutes. On the one hand, the opportunity to scale individual sentences to the crime and the offender has actually resulted in individualized sentences. However, as noted at the beginning of this article, some of the sentences are mild compared to punishments given for serious offenses in many national courts. This has prompted discussion among some victims and survivors that the sentences do not adequately reflect the gravity of the offense.

\section{Conclusion}

The ad hoc Tribunals have come a long way in short time. Their approaches to sentencing likely will become more settled and predictable over time. It appears that ICC judges will be guided by the sentencing practices of the ad hoc Tribunals, although they will not be bound by these practices. ${ }^{25}$ Moreover, the increased predictability of Tribunal sentences may, in the long term, encourage those domestic courts that - through the use of territorial, national, passive personality, ${ }^{26}$ or universal jurisdiction - prosecute human rights abusers to harmonize sentences for such prosecutions with inchoate international standards. 


\section{Notes}

1 This particularly is the case with the ICTR, whose sentences have been somewhat more consistent and systematic (and hence predictable) than those of the ICTY.

2 There is some difference between the definition of crimes against humanity in the Statutes of the two Tribunals, but this is not relevant for the purposes of this discussion.

3 For more details regarding the sentence appeal process, see Mark A. Drumbl \& Kenneth S. Gallant, Appeals in the Ad Hoc International Criminal Tribuna/s: Structure, Procedure, and Recent Cases, 3 J. App. Practice \& Process 589, 610-613 (2001). Prosecutorial appeals are found in many national legal systems, including common law jurisdictions (such as Canada).

4 For trials heid before the adoption of current ICTY Rule 87(C), Prosecutor v. Kunarac et al., ICTY Case No. IT-96.23 and IT.96.23/1 "Foca" (ICTY Appeals Ch., June 12, 2002), paras. $337-44$, validates the practice of assigning a single sentence.

5 Andrew N. Keller, Punishment for Violations of International Criminal Law: An Analysis of Sentencing at the ICTY and ICTR, 12 IND. INT'L \& COMP. L. Rev. 53, 68 (2001).

6 Rome Statute of the International Criminal Court, U.N. Doc. A/CONF. 183/9 (July 17, 1998), art. 76; Keller, supra note 5 , at 73. The ICC's constitutive document is called the Rome Statute.

7 Rome Statute, supra note 6, art. 77(1).

$8 \quad$ Id. art. 79.

- All judgments and constitutive documents are available at www.un.org/icty.

10 All judgments and constitutive documents are available at www.ictr.org. Some documents at this website are available only in French. The working languages of both Tribunals are French and English.

1 Prosecutor v. Krstic, ICTY Case No. IT.98-33, § 700 (ICTY Trial Ch., Aug. 2, 2001); Prosecutor v. Kambanda, ICTR Case No. ICTR-97-23 §§ 14-19 (ICTR Trial Ch., Sept. 4, 1998); Prosecutor v. Serushago, Case No. ICTR.98.39 §§ 15-16 (ICTR Trial Ch., Feb. 5, 1999). Accord Allison Marston Danner, Constructing a Hierarchy of Crimes in International Criminal Law Sentencing, 87 VA. L. REv. 415, 491-92 (2001).

12 Cases cited in note 11 , supra.

13 See, e.g., Procureur c/ Akayesu, Case No. ICTR 96-4-A, paras. 404-22 (ICTR Appeals, June 1, 2001) (no characterization of genocide as more serious than other crimes within the jurisdiction of the ICTR, but a life sentence for genocide was given) (full text in French only available at www.ictr.org).
14 ICTY Statute, art. 24; ICTR Statute, art. 23. ICC Statute, supra note 6 , art. 78, uses the word "shall" instead of "should."

15 Prosecutor v. Tadic, ICTY Case No. IT.94-1, 869 (ICTY Appeals Ch., Jan. 26, 2000).

16 Id., Separate Opinion of Judge Cassese, para. 19.

17 Serushago v. Prosecutor, ICTR Case No. 98.39-A (ICTR App. Ch. Apr. 6, 2000) (15 year single sentence for genocide and crimes against humanity following guilty plea, accompanied by cooperation with prosecutors and genuine remorse).

18 Prosecutor v. Kunarac et al., ICTY Case No. IT-96-23 and IT. 96.23/1 (June 12, 2002); Prosecutor v. Delalic, ICTY Case No. IT.96.21 $\$ 1194$ (Feb. 20, 2001).

19 Prosecutor v. Tadic, ICTY Case No. IT-94-1 (Jan. 26, 2000); Prosecutor v. Kambanda, ICTR Case No. ICTR-97.23 (Sept. 4, 1998); Prosecutor v. Rutaganda, ICTR Case No. ICTR.96.3 (Dec. 6, 1999); Prosecutor v. Delalic, ICTY Case No. IT.96.21 (Feb. 20, 2001); Prosecutor v. Kordic, ICTY Case No. IT-95. $14 / 2$ (Feb. 26, 2001).

20 Prosecutor v. Jelisec, ICTY Case No. IT.95.10 (July 5, 2001); Prosecutor v. Krnojelac, ICTY Case No. IT-97.25 (Mar. 15. 2002).

21 Prosecutor v. Serushago, Case No. ICTR-98.39 $\S \S 15-16$ (Feb. 5, 1999); Prosecutor v. Ruggiu, ICTR Case No. ICTR-97.32 (June 1, 2000); Prosecutor v. Todorovic, ICTY Case No. IT-95. 9/1 (July 31, 2001).

22 Prosecutor v. Jelisec, ICTY Case No. IT-95.10, (July 5, 2001); Prosecutor v. Erdemovic, ICTY Case No. IT-96.22 (Nov. 29 1996).

23 Prosecutor v. Delalic, ICTY Case No. IT.96.21 § 1194 (Feb 20, 2001).

24 Prosecutor v. Kunarac et al., ICTY Case No. IT.96.23 and IT. 96.23/1 (June 12, 2002).

25 To be sure, the ICC's statutory sentencing guidelines are not identical to those of the ad hoc tribunals. For example, it is unclear whether the ICC will make use of the nationał law that would otherwise be applied to the convicted person. See immi Tallgren, The Sensibility and Sense of International Criminal Law, 13 Europ. J. INT'L L. 561, 581 (2002). The ICC and the ad hoc Tribunals are separate legal institutions that are not formally bound by stare decisis. However, the ad hoc Tribunals are not bound inter se by stare decisis, yet frequently make reference to each other's jurisprudence as persuasive authority.

26 This means jurisdiction is based on the nationality of the victim rather than the perpetrator. 